\title{
Retro Brands in the Retailing Enviroment: A Review and Research Propositions
}

\author{
VOJVODIĆ Katija ${ }^{31}$
}

\begin{abstract}
Since the turn of the $21^{\text {st }}$ century, the rise of retro brands has been generating considerable interest in terms of stimulating positive emotions and influencing consumers' attitudes and retail buying behaviour. The paper presents the results of an extensive review of the recent literature on the role of retro brands in the retail context and consumer-related behaviour. As such, it provides a framework for an improved understanding of the overall retro phenomenon in the retailing environment. Useful insights for both retailers and marketers are provided in order to better understand the concept of retro branding and to enhance the overall retail experience of retro consumers. In addition, recommendations for further research are offered.
\end{abstract}

Keywords: retro brands, retailing environment, consumer nostalgia, retro marketing

JEL: M31

UDK: 658.625

659.113.25

COBISS.SR-ID 253514508

\section{Introduction}

Scholarly interest toward the retro marketing phenomenon, also referred as retromania and retro marketing revolution, started at the turn of the 21st century (Brown, 1999; Brown, 2001a; Brown, 2001b; Brown, 2001c; Brown, 2003; Brown, Kozinets, Sherry, 2003b; Brown, 2013). Nowadays, retro marketing is perceived as rampant (Stephen Brown, 2015). Looking back approach is increasingly becoming a way to accommodate changing consumer behaviour.

Although a retro-marketing approach involves looking to the past for marketing inspiration (Dacko, 2008), retro is not just a marginal movement (Castellano et al., 2013). Furthermore, the future of marketing is argued to lie in its past (Brown, 2001b).

In the context of the retail space, it has been suggested that the essential interplay between product, ritual and aesthetics creates positive moods of belonging and sharing and may increase satisfaction (Hamilton, Wagner, 2014). In addition to brand's physical attributes, brands that are associated with life event experiences can be stored in consumer memory (Ratnayake, Andrews, 2016).

Consequently, brands can acquire deep meaning for consumers by their involvement in the socialization process of growing up, and can evoke profound feelings of nostalgia and provide comfort from insecurity (Rosenbaum-Elliott, Percy, Pervan, 2015).

As stressed by Hallegatte and Marticotte (2016), consumption related to the past is trendy.

Nowadays, retail environments are designed intentionally to evoke memories of the past (Babin an, Borges, 2009). In general, nostalgia is widely considered to influence attitudes and

\footnotetext{
${ }^{31}$ University of Dubrovnik, Department of Economics and Business Economics, Dubrovnik, Croatia
} 
behaviours (Clay Routledge, 2015). Therefore, nostalgia evoked by brands is at the forefront of contemporary marketing theory and practice (Bartier, Friedman, 2013).

To advance understanding of retro brands in the retail environment, the paper presents the results of an extensive review of the recent literature on retro branding phenomenon. The purpose of the paper is to identify the main features of retro branding and retro consumers in the retail environment and to determine a framework for further analysis. To this end, the paper is divided into five sections. Following the introduction, the concept of retro branding is presented in the second section. The third section looks at the features of retro consumers, whereas directions of future work on both retro brands and consumers are analysed in the fourth section.

Finally, some conclusions are drawn in the last section.

\section{The concept of retro branding}

The term "retro branding" is generally defined as an alternative form of brand extension (Solomon et al., 2006). Retro brands usually refer to relaunched historical brands with updated features (Stephen Brown, Robert V. Kozinets, and John F. Sherry, 2003a). According to Kral (2012, p. 115), "retro branding refers to the revival or re-launch of a product or service brand from a prior historical period, which is usually, but not always, updated to contemporary standards of performance, functioning or taste". Similarly, Fons Van Dyck (2014) underlined that retro brands integrate old-fashioned design with modern functionality. With these new features, retro brands are "refitted into the market as a hip, new contemporary brand" (Franzen, Moriarty, 2015).

In that context, retro brands are recognised as a relatively safe and less-costly way to introduce a new product by reducing the risk of failure (Kral, 2012). As described by Kardes, Cronley, Cline (2011), marketers are taking successful old brands, updating them, and relaunching them with the hope of leveraging consumer nostalgia. On the other hand, Shetty, Raghavendra, Jyothis (2014) stressed that reviving the brands could be very risky and complex, especially when they inherited negative perceptions.

It is important to highlight that nostalgic brands are sometimes mistaken for retro brands.

Although retro brands are perceived as nostalgic (Hemetsberger, Kittinger-Rosanelli, Mueller, 2010), a distinction should be made between retro brands and pure nostalgic brands. As stressed earlier, the major difference is that retro brands include the attribute of updating.

Further, Dahlen, Lange, Smith (2010) linked the trend for retro brands with "nostalgic associations which transfer us to a different place or time in our lives through memories of family, youth or formative years". In the sense of nostalgic attachment, it is argued that the brand should evoke pleasant memories because the consumer used it in the past (Chernatony, McDonald, Wallace, 2011).

In addition, Brown, Kozinets, and Sherry (2003a) emphasized that retro brand management involves an uneasy, cocreative, and occasionally clamorous alliance between producers and consumers. Moreover, Brown (2016) addressed boomerang brands as a suitable metaphor for the rise of retro brands. Apart from being nostalgic objects, retro brands can be seen as identity building by providing strong historical value systems to identify with (Hemetsberger, KittingerRosanelli, Mueller, 2010). Likewise, Brown, Kozinets, Sherry (2003a) emphasised that retro brands invoke brand heritage that triggers personal and communal nostalgia.

Additionally, Strauss (2008) argued that the current boom in retro brands had a strong foundation in the trustworthiness of, and experience with, old brands. Further, Balmer (2017) noted that retro brands celebrate an idealised and, sometimes imagined, past. In light of this, Hartmann, Brunk, Giesler (2016) developed a conceptual model of brand retrofication highlighting co-constitutive identity and retro branding relationship of commercial and political mythmaking. 


\section{Revealing retro consumers in the retail environment}

As observed by Levy, Weitz, Grewal (2014), the value of the brand is largely based on the associations that customers make with the brand name. With this in mind, many researchers associated retro brand consumption with feelings of nostalgia (Brown, Kozinets, Sherry, 2003a; Brown, Kozinets, and Sherry, 2003b; Dahlen, Lange, Smith, 2010; Schlegelmilch, Bodo, 2016; Solomon et al., 2014; Hemetsberger, Kittinger-Rosanelli, Mueller, 2010). However, Andrew Higson (2014) pointed out that the post-modern version of nostalgia erases the sense of distance between the past and the present. Furthermore, Baines, Fill (2014) addressed feelings of pseudo-nostalgia as many consumers are unlikely to have experienced the original brand.

Notwithstanding, as stressed by Shaughnessy (2015), what is nostalgic for one audience is not necessarily nostalgic for another.

Consumers are said to search for the brands that deliver additional value connected with feeling of security and calm (Grebosz, Pointet, 2015). Likewise, Ling Zhou et al. (2013) noticed that existential insecurity and social insecurity enhanced consumers' preference for nostalgic products. In addition, Bartier (2012) outlined three characteristics that form the power of nostalgia toward the brand, i.e., perceived oldness of brand, recall of consumers lived or learned past memories and elicitation of feelings. Further, Lemmetti, Tuominen (2017) pointed out that nostalgic brand associations could be drawn from either consumer's personal or communal associations.

Retro product consumption is often considered with psychological factors contributing to individuals' desires to live in the past (Cartwright, Besson, Maubisson 2013). It is also argued that nostalgia is intensely personal and that it works the best for current consumers who have personal attachments with the brand that they used during childhood (Sultan, Muehling, Sprott, 2010).

Furthermore, LaTour, LaTour, Zinkhan (2010) found that memories from early childhood were more predictive for understanding current brand attitudes than memories coming from adolescence.

Specifically, Muehling (2013) reported that responses of a personally nostalgic nature tended to predominate and were more influential in shaping brand attitudes. According to Schlegelmilch (2016), personal nostalgia is associated with individual life cycles.

Consequently, a growing number of older people is likely to be more interested in retro brands that help them to remember their youth. For example, i Kusumi, Matsuda, Sugimori (2010) claimed that aging facilitates a predisposition toward nostalgia. On the other hand, Hemetsberger, Kittinger-Rosanelli, Mueller (2010) confirmed that young consumers perceived retro brands to be special possessions that helped them coping with ambiguities in their search for identity.

In addition, retro consumers are considered to be tourists consuming a form of cultural heritage (Franklin, 2002). In light of this, Brown (2003, p. 131.) outlined that retro cunningly appeals to consumers' anti-marketing sentiments. The results of the study by DogerliogluDemir et al., (2017) revealed that high value integration consumers compared to low value integration consumers evaluated retro brands more favourably. In terms of eco-consciousness, consumers of retro style are often involved in reuse and renovation, and are less likely to purchase newly produced goods (Southerton, 2011).

\section{Looking back - seeing ahead: research propositions}

Bearing in mind the distinction between nostalgic brands and retro brands, the characteristics of retro consumers have not been dealt with in depth. Although nostalgia has a strong presence in the marketing of goods and services (Lasaleta, Sedikides, Vohs, 2014), the impact of nostalgic emotions on retro brand consumption is still poorly understood. In general, little is known about the role of nostalgia in shaping consumer behaviour for retro products. 
In fact, what is known about retro consumers is largely based on the links between retro brands consumption and feelings of nostalgia.

However, what directions should future retro branding research take? The role of consumers' affective state on their responses to retro brands are an intriguing area of research.

The effect of nostalgic feelings on customers' attitudes toward retro brands should be analysed. In that sense, previous work has failed to address the effects of personal and historical nostalgia on consumers' responses to retro brands. Likewise, the question arises how the type of nostalgia evoked influences consumers' attitudes toward retro brands. Gender differences appear to be worthy of future research, especially in terms of the impact of nostalgic feelings on consumer preference for retro brands. In addition to exploring gender differences, future research attention should also be devoted toward examining the impact of culture on the consumer relationship with retro brands and the overall cultural consumer environment of retro brands.

Nonetheless, little academic research has attempted to determine whether past brand associations influence purchase intentions of retro consumers and their attitudes toward retro brands. In addition, further work needs to be carried out to examine the impact of retail atmospherics on consumer behaviour associated with retro brand consumption. In light of this, Foster, McLelland (2015) proposed a brand dictated "theme" to create a more interactive, immersive, and authentic environment. Further, it is argued that evoking nostalgic feelings through design can generate positive emotions to enhance consumer satisfaction (Chen, 2014).

As regards packaging-related experiences, future work should also concentrate on the impact of nostalgic emotions on consumer satisfaction with retro packaging design.

Evidence suggests that consumers having nostalgic feelings toward a specific brand sometimes respond negatively to updated or modified versions of the brand Shields, Johnson, 2016).

In that context, the field of retro branding requires improved knowledge about effect of consumers' brand nostalgia on their responses to changes to a brand. The findings would provide insightful implications for marketers and retailers by identifying meaningful relationships between nostalgic feelings and retro brands.

In addition, deeper understanding of consumer behaviour in retro context in needed.

Moreover, the links between consumer age and preferences for retro brands are worth examining. Further studies on the topic should also address the main differences in retro brand attitudes between different generational cohorts (e.g., Baby Boomers, Generation X and Generation Y). Additional research is also needed in the area of consumer decisions, in particular the effects of retro marketing on consumer decisions. This is especially relevant for marketers in order to choose appropriate marketing and communication strategies to approach retro consumers.

\section{Conclusions}

As discussed earlier, over the past two decades, there has been a growing interest in the issue of retro marketing, in particular retro branding. In general terms, it can be argued that the concept of retro branding is well defined. On the other hand, there has been little discussion on retro consumers and, in particular, on determinants of consumer behaviour related to retro brands. Specifically, the evidence from the previous sections implies that the issue of retro consumers remains an under-researched topic. Nevertheless, due to the complexity of consumers' nostalgic feelings, thoughts and memories, an interdisciplinary approach should be considered to cover the issue in more depth.

The paper provides the synthesis of the most current theoretical and practical knowledge available on retro branding in the retailing environment. As such, the paper can serve as a basis for conducting future empirical research in the field. The findings presented in the paper may be useful to all subjects involved in creating retro philosophy of a brand. It also provides useful 
insights for retailers and marketers approaching retro consumers and developing retro products to meet their requirements.

However, in the context of retail environment, future work should primarily deal with triggers affecting retro brands consumption, as well as memories related to retailing experiences. Additionally, Hamilton, Wagner (2014) underlined that the emotional value of everyday experiences might directly influence consumer loyalty. Consequently, enhancing consumers' relationship with retro brands may result in improving brand loyalty. For these reasons, understanding retro consumers is crucial for both retailers and marketers in order to target this market segment more effectively. Finally, bearing in mind that no empirical analysis has been undertaken, the paper lacks a contribution to the field from an empirical point of view.

To this end, additional research is needed to provide empirical support to broaden current knowledge of both retro brands and retro consumers in the retail environment.

\section{REFERENCES}

1. Babin, B. J., Adilson, B. (2009). "Oh yeah, I remember that store! Memory, experience, and value." In Memorable Customer Experiences: A Research Anthology, eds. Adam Lindgreen, Joelle Vanhamme, Joelle and Michael B. Beverland, 161-176. Burlington: Gower Publishing.

2. Baines, P., Fill, C. (2014). Marketing. Oxford: Oxford University Press.

3. Balmer, J. M. T. (2017). "Corporate heritage identities, corporate heritage brands and the multiple heritage identities of the British Monarchy." In Foundations of Corporate Heritage, ed. John M. T. Balmer, 21-43. New York: Routledge.

4. Bartier, A.L. (2012). "Things were better before: what is the power of nostalgia toward the brand?" Paper presented at 11th International Marketing Trends Conference, Venice, Italy, 1921 January 2012

5. Bartier, A.L., Friedman, M. (2013). "Nostalgia Evoked by Brands: A First Step Towards Scale Development and Validation", Ideas in Marketing: Finding the New and Polishing the Old, ed. Krzysztof Kubacki, Proceedings of the 2013 Academy of Marketing Science (AMS) Annual Conference, 392-392.

6. Brown, S. (1999). "Retro-marketing: yesterday's tomorrows, today!” Marketing Intelligence \& Planning, 17(7): 363-376.

7. Brown, S. (2001a). "Marketing for Muggles: Harry Potter and the Retro Revolution." Journal of Marketing Management, 17(5-6): 463-479.

8. Brown, S. (2001b). Marketing - The Retro Revolution. London: Sage Publications Ltd.

9. Brown, S. (2001c). "The retromarketing revolution: l'imagination au pouvoir." International Journal of Management Reviews, 3(4): 303-320.

10. Brown, S. (2003). "Let's do the time warp again: a marketing manifesto for retro revolutionaries." In The Future of Marketing: Critical $21^{\text {st }}$ Century Perspectives, ed. Philip J. Kitchen, 125-139. London: Palgrave Macmillan.

11. Brown, S. (2013). "Retro from the get-go: reactionary reflections on marketing's yestermania." Journal of Historical Research in Marketing, 5(4): 521-536.

12. Brown, S. (2015). "When innovation met renovation: Back to the future of branding." Marketing Intelligence and Planning, 33(5): 634-655.

13. Brown, S. (2016). Brands and Branding. London: SAGE Publications Ltd

14. Brown, S., Kozinets, R.V., Sherry, J.F. (2003a). "Teaching old brands new tricks: Retro branding and the revival of brand meaning." Journal of Marketing, 67(3): 19-33.

15. Brown, S., Kozinets, R.V., Sherry, J.F. (2003b). "Sell Me the Old, Old Story: Retromarketing Management and the Art of Brand Revival." Journal of Customer Behaviour, 2(2): 133-147.

16. Cartwright, P. A., Besson, E., Maubisson, L. (2013). "Nostalgia and technology innovation driving retro music consumption." European Journal of Innovation Management, 16(4): 459494.

17. Castellano, S., Ivanova, O., Adnane, M., Safraou, I., Schiavone, F. (2013). "Back to the future: adoption and diffusion of innovation in retro-industries." European Journal of Innovation Management, 16(4): 385-404.

18. Chen, J. C.C. (2014). "The impact of nostalgic emotions on consumer satisfaction with packaging design." Journal of Business and Retail Management Research, 8(2): 71-79. 
19. Dacko, S., G. (2008). The Advanced Dictionary of Marketing: Putting Theory to Use. Oxford: Oxford University Press.

20. Dahlen, M., Lange, F., Smith, T. (2010). Marketing Communications: A Brand Narrative Approach. West Sussex: John Wiley \& Sons Ltd.

21. De Chernatony, L., Malcolm McDonald, M., Wallace, E. (2011). Creating Powerful Brands. Oxford: Butterworth-Heinemann.

22. Dogerlioglu-Demir, K., Tansuhaj, P, Cote, J., Akpinar, E. (2017). "Value integration effects on evaluations of retro brands." Journal of Business Research, 77: 124-130.

23. Dyck, F. V. (2014). Advertising Transformed: The New Rules for the Digital Age. London: Kogan Page Limited.

24. Foster, J., McLelland, M.A. (2015). "Retail atmospherics: The impact of a brand dictated theme." Journal of Retailing and Consumer Services, 22: 195-205.

25. Franklin, A. (2002). "Consuming design: consuming retro." In The Changing Consumer: Markets and Meanings, eds. Steven Miles, Alison Anderson, Kevin Meethan, 90-103. London: Routledge.

26. Franzen, G., Moriarty, S. (2015). The Science and Art of Branding. New York: Routledge.

27. Grebosz, M., Pointet, J.M. (2015). "The Retro" Trend in Marketing Communication Strategy of Global Brands." Journal of Intercultural Management, 7(3): 119-132.

28. Hallegatte D., Marticotte, F. (2016). "Nostalgia's Role in Retromarketing". In Celebrating America's Pastimes: Baseball, Hot Dogs, Apple Pie and Marketing? ed. Kacy K. Kim, Developments in Marketing Science: Proceedings of the Academy of Marketing Science. 747748. Cham: Springer.

29. Hamilton, K., Wagner, B.A. (2014). “Commercialised nostalgia: Staging consumer experiences in small businesses.” European Journal of Marketing, 48(5/6): 813-832.

30. Hartmann, B. J., Brunk, K.H., Giesler, M. (2016). "Brand Retrofication: How East German Consumers Animate a Retro Brand Market to Create a Revisionist Eastern Consumption Culture". In NA - Advances in Consumer Research, eds. Page Moreau, and Stefano Puntoni, Duluth, MN: Association for Consumer Research, 44: 257-263.

31. Hemetsberger, A., Kittinger-Rosanelli, C., Mueller, B. (2010). "Grandma's fridge is cool - The meaning of retro brands for young consumers.” Advances in Consumer Research, 38: 242-248.

32. Higson, A. (2014). "Nostalgia is not what it used to be: heritage films, nostalgia websites and contemporary consumers." Consumption Markets \& Culture, 17(2): 120-142.

33. Kardes, F. R., Cronley, M.L., Cline, T.W. (2011). Consumer Behaviour, Mason: South-Western Cengage Learning.

34. Kral, P. (2012). "Nostalgic Branding in Central Europe." In Diversity in European Marketing: Text and Cases, eds. Thomas Rudolph, Bodo B. Schlegelmilch, Josep Franch, Andras Bauer, and Jan N. Meise, 113-130. Wiesbaden: Springer Gabler.

35. Kusumi, T., Matsuda, K., Sugimori, E. (2010). "The effects of aging on nostalgia in consumers' advertisement processing." Japanese Psychologic Research, 52(3): 150-162.

36. Lasaleta, J. D., Sedikides, C., Vohs, K. D. (2014). "Nostalgia weakens the desire for money." Journal of Consumer Research, 41 (3): 713-729.

37. LaTour, K., LaTour, M.S., Zinkhan, G.M. (2010). "Coke is It: How stories in childhood memories illuminate an icon." Journal of Business Research, 63(3): 328-336.

38. Lemmetti, H., Tuominen, P. (2017). "Expatriates' Nostalgic Brand Relationships. Case Fazer Blue Chocolate." In Regional Studies on Economic Growth, Financial Economics and Management, Proceedings of the 19th Euroasia Business and Economics Society Conference, eds. Mehmet Huseyin Bilgin, Hakan Danis, Ender Demir, and Ugur Can, 401-422.

39. Levy, M., Weitz, B.A., Grewal, D. (2014). Retailing Management. New York: McGraw-Hill Education.

40. Muehling, D. D. (2013). "The relative influence of advertising-evoked personal and historical nostalgic thoughts on consumers' brand attitudes. "Journal of Marketing Communications", 19(2), 98-113.

41. Nikoukar, Gh., Divandari, A., Ebrahimi, A., Esfidani, M.R. (2009). Patterns of consumer behavior and internet marketing strategies: Household Iran. College of Business Administration. No. 2. 150-135.

42. O'Shaughnessy, J. (2015). Competitive Marketing (RLE Marketing): A Strategic Approach. London: Routledge.

43. Pitta, D.A., Fowler, D.E. (2013). Online consumer communities and their value to new product developers, Journal of product and Brand Management, Vol.14 (5), PP. 283-291. 
44. Ratnayake, N., Andrews, P. (2016). "Power of Brands in Recalling Nostalgic Memories Among Young Adults: An Exploratory Study." In Let's Get Engaged! Crossing the Threshold of Marketing's Engagement Era, Proceedings of the 2014 Academy of Marketing Science (AMS) Annual Conference, eds. Michael W. Obal, Nina Krey, and Christian Bushardt, 349-354., Springer International Publishing.

45. Rosenbaum-Elliott, R., Percy, L., Pervan, S. (2015). Strategic Brand Management. Oxford: Oxford University Press.

46. Roshandel, A. T., Sotovvati, F. (2012). Iranian television commercial advertising the effects on investment incentives. Volume 7. Number 2. Ss.194-159.

47. Routledge, C. (2015). Nostalgia: A Psychological Resource. New York: Psychology Press Taylor \& Francis.

48. Schlegelmilch, B. B. (2016). Global Marketing Strategy: An Executive Digest. Springer International Publishing Switzerland.

49. Shah Mohammadi, A., Ahmadi Oskouie, N. (2011). The city of Mashhad measure people's attention to the commercials broadcast by local television. 13. Number Media Studies pp. 231217.

50. Shetty, A. S., Raghavendra, A.N., Jyothis, M. (2014). "Revival of the Relics: How to Find Gold in the Brand Cemetery?" Global Management Journal, 6(1-2): 12-21.

51. Shields, A. B., Johnson, J.W. (2016). "What Did You Do to My Brand? The Moderating Effect of Brand Nostalgia on Consumer Responses to Changes in a Brand." Psychology and Marketing, 33 (9): 713-728.

52. Solomon, M. R., Bamossy, G., Askegaard, S., Hogg, M.K. (2006). Consumer Behaviour: A European Perspective. Harlow: Prentice Hall.

53. Solomon, M., Hughes, A., Chitty, B., Marshall, G., Stuart, E. (2014). Marketing: Real People, Real Choices. Frenchs Forest, NSW: Pearson Australia.

54. Southerton, D. (2011). Encyclopedia of Consumer Culture. London: Sage Publications Ltd.

55. Strauss, R. E. (2008). Marketing Planning by Design: Systematic Planning for Successful Marketing Strategy. West Sussex: John Wiley \& Sons Ltd.

56. Sultan, A. J., Muehling, D.D., Sprott, D.E. (2010). "The effect of personal attachment and usage on consumers' response to nostalgia". The Academy of Marketing Studies Proceedings, 15(2): 13., Allied Academies International Conference, Las Vegas.

57. Tong, X., Hawley, J. (2009). Measuring customer-based brand equity: empirical evidence from the sportswear market in China, Journal of Product \& Brand Management, Vol 18(4), PP. 262 271.

58. Trehan, M., Trehan, R. (2007). Advertising and Sales Management, New Delhi: India enterprise.

59. Yoo, B., Lee, S.H. (2009). Buy genuine luxury fashion products or counterfeits? Advances in Consumer Research, 36, 280-286.

60. Zhou, L., Wang, T., Zhang, Q., Mou. Y. (2013). "Consumer insecurity and preference for nostalgic products: Evidence from China.” Journal of Business Research, 66(12): 2406-2411.

\section{Article history:}

- $\quad$ Received 9 December 2017

- $\quad$ Accepted 19 December 2017 